\title{
Modification: The Self-Help Specific Performance Remedy
}

\author{
Subha Narasimhan $\dagger$
}

\begin{abstract}
In this Article, Professor Narasimhan examines the relationship between the doctrine of modification and the extraordinary contract remedy of specific performance. The author argues that an anomaly in modern modification doctrine enables the party who accepts the other party's modified terms to exploit the contractual relationship. The party agreeing to new contractual terms may receive performance and then contest the modification in court. If successful in challenging the modification, the party effectively will have received specific performance. Professor Narasimhan argues that this self-help remedy is available even when the party would not have been awarded specific performance in an action for breach of the original contract. The author argues that modification doctrine should minimize this opportunity for exploitation by ensuring that the self-help remedy is available only when specific performance would have been the appropriate remedy in enforcing the original contract. .
\end{abstract}

The doctrine of modification currently reflects the view that contracting parties must have some flexibility to adjust the terms of their relationship to changing conditions. The modern development of this doctrine has seen the de-emphasis of traditional, mechanical modification theories, which were based upon formalistic notions of consideration, and a move toward doctrine that questions whether modified contractual terms are the product of opportunism and duress. ${ }^{1}$ The modern approach to modification seeks to accommodate the parties' need for flexibility while limiting the danger that one party may use the leverage provided by the contractual relationship to extract unfair concessions from the other. ${ }^{2}$ The challenge, then, as seen by courts, commentators and codifiers alike, lies in formulating doctrine to allow for ongoing adjustment while policing for opportunistic attempts to exploit the contractual relationship.

Despite the new emphasis on ferreting out opportunism, the potential

$\dagger$ Professor of Law, Columbia Law School. B.S., 1970, University of London; M.S., 1972; Ph.D., 1975, Stanford; J.D., 1980, Columbia. Financial Support from the Center for Law and Economic Studies at Columbia Law School is gratefully acknowledged. I would also like to thank Professors Bruce $\Lambda$. Ackerman and W.F. Young for their helpful comments during the preparation of this Article.

1. See, e.g., Muris, Opportunistic Behavior and the Law of Contracts, 65 MinN. L. REv. 521, 532-37 (1981); J. White: \& R. Summers, Handbook of The LAw Under The. Uniform ComMERCiAl. CONE 46-49 (2d ed. 1980).

2. See, e.g., Muris, supra note 1, at 522-24. 
for exploitation remains. This Article focuses on one type of opportunism that is manifested in what I call the "self-help specific performance remedy." In a standard contractual relationship, the promisor effectively has a choice between performing or breaching and then paying damages: Typically, remedies for breach do not include specific performance. ${ }^{3}$ If the promisor proposes a modification of the contract's terms, the promisee is presented with a potentially exploitative self-help remedy: She can agree to modify a contract, receive performance, and then contest her obligation under the modified agreement. Where specific performance is not available in an action for breach, a promisee might gain more from contesting a modification after receiving performance than she could from a suit to enforce the original contract.

The problem of promisee opportunism has been largely ignored, probably because modification doctrine has traditionally viewed only one party-the party seeking to modify-with suspicion. Traditional modification doctrine proceeds from the premise that only the party requesting modification seeks to gain more than his due under the contract. The other party, after all, is entitled to her contractual rights as promised.

This traditional view of modification is viable only under either or both of two unsound assumptions. First, the promisee would be free from suspicion if she were entitled to performance, rather than a choice, at the promisor's option, between performance and damages for breach. The promisee, then, could not receive more than the legal remedy for breach

3. While some argue that promisors should not have the choice between breach and performance, contract remedies are formulated under this view of contractual obligation. See infra text accompanying notes 16-19.

4. In a contractual relationship, of course, both parties have made promises. For the sake of simplicity, this Article refers to the person seeking modification as the "promisor," and the party consenting to modification and seeking enforcement of the original promise as the "promisee."

5. See infra text accompanying notes $29-42$.

The paradigmatic "coerced" modification case of Alaska Packers' Ass'n v. Domenico, 117 F. 99 (9th Cir. 1902), illustrates this point. $\Lambda$ group of seamen entered into independent contracts in San Francisco with the defendant in which they agreed to sail on the defendant's vessel to Alaska, work there for an entire fishing season, and then return to San Francisco on the defendant's ship. Upon arrival in Alaska, the seamen, acting collectively, refused to work unless the defendant raised their wages. Because no other workers were available in Alaska, the defendant agreed to the seamen's demands. The men completed their work as agreed. When they demanded their wages after their return to San Francisco, the defendant refused to honor the modifications. The Ninth Circuit refused to enforce the modifications on the grounds that they were based upon a preexisting ciuty, and hence lacked consideration. Yet, if the defendant had instead sought to enforce the contracts, it would have been unable to obtain specific performance. The contracts at issue were paradigmatic examples of personal service contracts, for which specific performance will not be granted. Defendant might have been able to secure injunctions against the men working elsewhere as seamen, depending upon whether other types of jobs were available. See infra notes 142-43 and accompanying text.

While the preexisting duty rule is no longer generally used to police modifications, the modification in Alaska Pachers' is unlikely to fare any better under current doctrine. To enforce the modifications plaintiffs would have to show that the modifications were "fair and equitable in view of circumstances not anticipated by the parties when the contract was made," REsTritrmenr (Sriond) of CONTRACTS $\$ 89$ (a) (1981) [hereinafter RistaTkMEN'], and the court rejected any such claim. $117 \mathrm{~F}$. at 102. To the extent that a promisee's conduct is policed, defendant's conduct would pass muster. See infra note 70 and accompanying text. 
by modifying the contract to induce the promisor to perform and later contesting the modification. ${ }^{6}$ Second, such a one-sided view of modification opportunism might be justified if self-help remedies were a special category of remedy that need not be consonant with the underlying structure of contract law.

Specific performance is not the preferred remedy in contract law. ${ }^{7}$ Contract remedy, in most cases, is substitutional, designed to allow promisors the choice between performance or breach with the payment of damages. ${ }^{8}$ Moreover, the substitutional damage remedy often fails to compensate promisees adequately for their losses. ${ }^{\circ}$ This shortfall increases a promisee's incentives to modify a contract, receive the benefit of performance and then contest the modification later, because there is a discrepancy between the value of the performance and the damages available upon breach.

The second assumption-that self-help measures are independent of the general scheme of contract remedy-is equally untenable. This Article argues that self-help measures that allow parties more than they are entitled to under the remedial system must be considered opportunistic attempts by promisees to obtain more than their contractual rights. ${ }^{10}$ Self-help enforcement measures must be integrated into the general fabric of contract remedy. ${ }^{11}$

6. Of course, if the promisor could meet the legal standards for excuse, he could retain the right to change the performance due.

7. Some commentators may support a modification remedy that allows a promisee specific performance because they believe that the law of damages is inappropriate. They would argue, on either efficiency or moral grounds, that specific performance should be the preferred remedy for breach. See infra notes 91-96 and accompanying text. But these arguments are better addressed to correcting the underlying law of remedy than to the law of modification. Providing a self-help route to rights greater than those available under remedies for breach leads to other moral and strategic problems. See infra notes 99-104 and accompanying text.

8. See infra text accompanying notes 16-19.

9. Incomplete compensation results because many types of loss are non-compensable, such as subjective elements of value and losses unforeseen at the time of contracting. See infra text accompanying notes $20-26$.

10. Current doctrine does seek, to some extent, to police the manner and situations in which promisees may consent to modifications which they later contest. Such policing occurs in two ways: First, some courts have placed what appears to be a moral limitation upon a promisee's right to "trick" or "surprise" the promisor into performance by requiring that the promisee protest the modification before she consents. See, e.g., United States ex rel. Crane Co. v. Progressive Enters., Inc., 19 U.C.C. Rep. Serv. (Callaghan) 1306 (E.D. Va. 1976). Second, a promisee may be asked to demonstrate that she had no reasonable alternative to consenting to the modification. But here the inadequacy of substitutional relief to provide full compensation and the unavailability of specific performance are considered justifications for a promisee's conduct. See infra text accompanying note 79 . The limitations therefore fail to integrate a promisee's right to modify a contract, receive performance and later renege upon the modification with a promisee's legal remedies for breach.

11. It is curious that the self-help remedial nature of modification doctrine has hitherto been ignored. I suggest that this is because self-help measures are often considered outside the purview of the state's legal apparatus. This view of "private" action as being somehow independent of state control and choice, although endemic within the legal community, is being attacked on some fronts. See, e.g., Sunstein, Lochner's Legacy, 87 Cot.um. L. REv. - (forthcoming 1987) (arguing that in establishing base line for constitutional adjudication, status quo must also be regarded as choice by state). Surely, the conscious forming of legal doctrine and enforcement mechanisms to allow promisees 
Analysis of modification should proceed under the assumption that both contracting partners have the capacity and the incentive to alter contractual rights to receive more than they are entitled to under the initial contract. ${ }^{12}$ Section I of this Article demonstrates that current modification doctrine provides a self-help remedy of specific performance to the promisee. When promisors threaten to breach, promisees often will find it advantageous to modify in order to induce performance because damage rules are undercompensatory. ${ }^{13}$ Section I concludes that promisees may often successfully contest modifications after receiving performance, even though specific performance would not have been awarded in a suit to enforce the contract.

Section II sets forth the scope of a justifiable self-help remedy of specific performance. There is much controversy over the most appropriate remedy for breach. A self-help remedy of specific performance cannot be justified where specific performance is not the preferred remedy in a suit for enforcement: The self-help remedy does little to enhance the goals of contract law and increases the potential for opportunistic behavior by allowing parties to circumvent the limits placed upon recovery by the remedial system. The self-help remedy is most appropriate when a promisee is entitled to specific performance in a suit to enforce. It is also permissible when the damage remedy is considered legally inadequate but specific performance is unavailable because of limitations in the judicial administration system. ${ }^{14}$

to achieve particular results presents even stronger arguments for state control, and such doctrine should be made consonant with the underlying goals and objectives of the contract law.

12. The legal community does police opportunistic attempts by a promisor, the party secking modification, to reallocate contract rights. Both the U.C.C. and the Restatement explicitly require the policing of promisor opportunism, see infra notes 60-70 and accompanying text, and much scholarship has been devoted to elaborating the content of the policing requirement. See, e.g., Hillman, Policing Contract Modifications Under the UCC: Good Faith and the Doctrine of Fconomic Duress, 64 IowA L. Rrv. 849 (1979); Mather, Contract Modification Under Duress, 33 S.C.L. Rev. 615 (1982); Muris, supra note 1, at 532-52; Robison, Enforcing Extorted Contract Modifications, 68 lowa L. REv. 699 (1983). I will not pursue promisor opportunism further in this $\Lambda$ rticle.

Courts often have reacted against the restrictive preexisting duty rule by enforcing modifications without the required scrutiny of the promisor's conduct. See, e.g., Pirrone v. Monarch Wine Co., 497 F.2d 25 (5th Cir. 1974). To this extent, the problem of promisee opportunism, which arises only when modifications are not enforced, is avoided. But since doctrine requires a scrutiny of promisor's conduct, it is likely that courts will uniformly, if gradually, impose limits on opportunistic modifications by promisors.

13. Rules such as the foresecability requirement of Hadley v. Baxendale, 9 Ex. 341, 156 Eng. Rep. 145 (1854), often result in significant undercompensation upon breach. See infra text accompanying notes 21-26.

14. For example, courts may refuse to order specific performance because of the burden of supervision. See infra text accompanying notes 124-27. 


\section{Modification and Specific Performance}

\section{A. Modification as Remedy: The Nature of the Right}

Modification doctrine allows a promisee to agree to a change in the terms of the contract in order to induce a promisor to perform as promised in the contract and contest the change after the performance has been rendered. To the extent that the promisee's modified return performance is not enforced, modification doctrine gives the promisee, at her option, an avenue to obtain the performance promised in the initial contract at the initial price. It therefore provides a self-help remedy of specific performance. ${ }^{15}$

In the case of breach, contracts are usually enforced by an award of expectation damages. ${ }^{16}$ Expectation damages supposedly replace the value of the contract as if it had been performed; ${ }^{17}$ but they are not meant to compel the breaching party to perform. ${ }^{18}$ The breaching party is given a choice between breach, with payment of expectation damages to the other party, and performance. ${ }^{18}$ In theory, as long as the promisee is compensated for the breach, giving the promisor this choice will result in a benefit to the promisor at no cost to the promisee, with a net beneficial effect on contractual freedom and economic efficiency.

But expectation damages usually fail to provide full compensation for breach. This shortfall can occur for several reasons: (1) Damages can be awarded only after litigation, and most litigation costs are noncompensable. (2) Promisees must replace the promised performance at the time of breach; damages will be awarded only after trial. Interest charges in the interim are not compensable, and delays in receipt of the damages

15. See, e.g., Roth Steel Prods. v. Sharon Steel Corp., 705 F.2d 134 (6th Cir. 1983) (plaintiff agreed to price increase in order to induce supplier to continue supplying steel); Pirrone v. Monarch Wine Co., 497 F.2d 25 (5th Cir. 1974) (winemaker Pirrone consented to modification to induce wholesaler Monarch to order out brandy clogging Pirrone's facilities as required by their contract; remedy would have been unavailable in suit to enforce contract); see also $\mathrm{T}$ \& $\mathrm{S}$ Brass \& Bronze Works v. Pic-Air, Inc., 790 F.2d 1098 (4th Cir. 1986) (plaintiff induced timely delivery of plumbing supplies by agreeing to modification, which it later successfully contested, requiring plaintiff to pay shipment costs).

16. When the contract breached involves a sale of goods, buyers may also cover by arranging a reasonable substitute transaction, and then recovering the difference between the cover price and the contract price. U.C.C. \$ 2-712 (1977).

17. Expectation damages, in theory, place the breached-against party "in as good a position as he would have been in had the contract been performed." E.A. FArNSworth, Contracts $\S 12.1$, at 812 (1982); see also Rrsintiminit, supra note 5, $\$ 344$ comments a \& b.

18. "Our system of contract remedies is not directed at compulsion of promisors to prevent breach; it is aimed, instead, at relief to promisees to redress breach." E.A. FARNSworth, supra note $17, \S 12.1$, at 812 .

19. For a recent article voicing dissatisfaction with this state of affairs, see Linzer, On the Amorality of Contract Remedies-E.fficiency, Equity, and the Second Restatement, 81 Colum. L. Rev. 111 (1981). Linzer, and those who share his view, receive support from the Restatement, supra note 5, § 251 and the U.C.C. \$ 2-609 comment 1 (1977) (purpose of contracts is to secure performance, not mere promise of performance plus right to win lawsuit; but in event of breach remedies are still limited to replacement damages). 
after trial are often compensated at a low rate of interest. ${ }^{20}$ (3) Delay in arranging a substitute performance might jeopardize promisees' interests. ${ }^{21}$ (4) Promisees often are unable to prove some losses with adequate certainty, especially for subjective elements of value. (5) Some elements of loss are not compensable. In particular, the rule of Hadley v. Baxendale ${ }^{22}$ does not allow recovery for losses which could not be anticipated by the breaching party. ${ }^{23}$ (6) Some promised performances have no close substitutes, and promisees cannot arrange satisfactory alternatives. For example, goods may be unique, or the contract may be one for personal services whose nature is a matter of personal taste. ${ }^{24}$ (7) In a related vein, the goods may be scarce. ${ }^{25}$ (8) In some cases, damages are inadequate because the relationship between the promisor and the promisee has generated benefits that can be exploited if the promisor continues to deal with the promisee. ${ }^{28}$ Thus, in most cases, promisors may breach without fully compensating promisees.

Where the remedy of expectation damages is legally inadequate, ${ }^{27}$ promisees may be entitled to receive specific performance. But specific performance is considered an extraordinary remedy. The inadequacy of the damage remedy will not always justify an award of specific performance. ${ }^{28}$ Nor does specific performance result in a fully compensatory remedy: Litigation costs and delay costs, for instance, are not recoverable even if specific performance is awarded.

20. Interest after judgment is usually awarded at a legal-not the market-rate.

21. For example, in Austin Instrument, Inc. v. Loral Corp., 29 N.Y.2d 124, 272 N.E.2d 533, 324 N.Y.S.2d 22 (1971), the contract goods were sufficiently specialized that it would have taken months to receive substitutes, and the promisee was committed to deliver on a supply contract of its own.

22. 9 Ex. 341, 156 Eng. Rep. 145 (1854).

23. See Pirrone v. Monarch Wine Co., 497 F.2d 25 (5th Cir. 1974). Pirrone's attempt to get Monarch to move the brandy out by agreeing to a modification, rather than by storing the brandy and suing to enforce the contract was in part motivated by non-compensable damages. See supra note 15 . The compensability of the storage charge would have been questionable under Hadley v. Baxendale, 9 Ex. 341, 156 Eng. Rep. 145 (1854).

24. For example, the sale of a particular Picasso or a contract with Picasso for a portrait is a unique personal service.

25. See, e.g., Laclede Gas Co. v. Amoco Oil Co., 522 F.2d 33 (8th Cir. 1975). In that case, the promisee was attempting to enforce a fuel supply contract during the energy crisis. There was a market for the goods, but the available supply was already committed io past customers.

26. For instance, the promisee might have trained its employees to use the promisor's product. If those skills are not transferable to another product, they can only be exploited if the promisor continues to deal with the promisee. The loss of this "learning by doing" advantage is usually noncompensable.

27. Restatement, supra note 5, \$359(1). U.C.C. § 2-716(1) (1977) allows specific performance where goods are unique or in "other proper circumstances." Comment 2 to that section suggests that "inability to cover is strong evidence of "other proper circumstances."

28.

In determining whether the remedy in damages would be adequate, the following circumstances are significant:

(a) the difficulty of proving damages with reasonable certainty,

(b) the difficulty of procuring a suitable substitute performance by means of money awarded as damages, and

(c) the likelihood that an award of damages could not be collected.

Restatemeivi, supra note 5, $\$ 360$. 
Against this background of contract remedies for breach, let us consider an example. ${ }^{29}$ Buyer-promisee $(B)$ has a contract for the supply of electrical parts with Seller-promisor $(S) . B$ intends to use the parts to assemble a system that she is under contract to supply to her own customer $(C)$. The contract between $B$ and $C$ provides for fines if $B$ does not meet the delivery date. Moreover, $C$ is $B$ 's major customer and will continue his relationship with $B$ only as long as $B$ continues to be reliable. Before the delivery date set in $B$ 's contract with $S, S$ informs $B$ that he will be unable to fulfill his contract unless $B$ agrees to an increase in price. $B$ checks other suppliers: They are committed to contracts of their own, but will be able to supply $B$ at a price between the contract price and the suggested modified price, but at a later date than that set in $B$ 's contract with $S$. The delay will cause $B$ to miss her delivery date with $C$, but $B$ can eventually deliver the system. In addition, $S$ is $B$ 's usual supplier of electrical parts. $B$ has not dealt with any of the other suppliers before; while their reputations are good, $B$ has no firsthand knowledge about the reliability of their parts and their compatability with $B$ 's own product. How should $B$ respond to $S$ ?

$B$ has several options: $B$ may refuse, arrange an alternate transaction and sue $S$ for damages; $B$ may refuse and sue $S$ for specific performance; $B$ may agree to the modification, receive the performance from $S$ and contest the modification later; ${ }^{30}$ or $B$ may consent to the modification and not contest.

\section{B Refuses and Sues for Damages}

By refusing $S$ 's demand and arranging a substitute transaction, $B$ will have to pay more for the parts. Since $B$ will be late under her delivery contract with $C$, she will be liable for the contractual fine and might also

29. The example is a variant of the facts of Austin Instrument, Inc. v. Loral Corp., 29 N.Y.2d 124, 272 N.E.2d 533, 324 N.Y.S.2d 22 (1971). Loral was awarded a Navy contract for the production of radar, containing a liquidated damages clause for late deliveries and a cancellation clause for defaults. Loral subcontracted with Austin for gear components to manufacture the radar units.

Later, Loral was awarded a second Navy contract for radar units. When Loral attempted to solicit bids on gear components for the second contract, Austin threatened to cease deliveries on the first subcontract unless Loral both raised the price on the first subcontract and awarded the second gear contract to Austin. After checking for an acceptable alternative supplier, Loral consented to Austin's demands. After timely completion of both contracts, Loral sued on the first contract for restitution of the excess of the modified price over the original contract price.

30. This option might, in fact, be considered two options because courts often treat recoveries of additional payments made under modified contracts differently from enforcement of modifications. Traditionally, modification doctrine, derived from consideration doctrine, has technically been related only to the enforceability of modifications. Once a promisee had performed the modified contract, her only recourse to coniest the modified price was to claim duress. Thus, if $B$ was not obliged to make payment until after delivery, $S$ would have to sue for enforcement of the modification. If $B$ had to prepay, $B$ would have to sue under the more stringent standards of duress, see infra note 62 , for restitution of the "excess" payment. See E.A. FARNSWORTH, supra note 17, §§ 4.21-4.22, at 271-79. This dichotomy persists. For the purposes of this Article, however, both alternatives are treated as one option, governed by the laws of modification. 
lose $C$ 's goodwill and chances to enter into future contracts. $B$ will lose the benefit of her experience in using $S$ 's parts, a loss which could have adverse consequences not only for this supply contract, but for future ones as well. ${ }^{32}$

The damage remedy will compensate $B$ for the excess of the replacement price over the contract price and the costs of actually arranging the substitute transaction. However, $B$ might not be compensated for other losses. To recover for the fine she will pay $C, B$ will have to show that $S$ could have foreseen this $\operatorname{loss}^{32}$ at the time of contracting. ${ }^{33} B$ will certainly not recover for lost opportunities of future relationships with $C$, on the grounds of either unforeseeability ${ }^{34}$ or uncertainty. ${ }^{35}$ Nor will $B$ be compensated for losing her informational advantages in dealing with $S{ }^{38}$

$B$ will not recover most of her litigation costs. $B$ will also face a delay between the time she has to pay the substitute supplier and the time she receives payment from $S$. The opportunity cost of that capital is not an element of $B$ 's recoverable damages. ${ }^{37}$

\section{B Refuses and Sues for Specific Performance}

If $B$ prevails in a suit for specific performance she will receive the parts from $S$ at the contract price, but not until the conclusion of litigation. In addition, $B$ might be uncertain of the quality of $S$ 's enforced performance. While $B$ is more likely to be reimbursed for delay fines than she would be in a suit for damages, she remains unlikely to recover for loss of customer goodwill and lost opportunity $\operatorname{costs}^{\mathbf{3 8}}$ or informational and relational ad-

31. If this contract had been performed to $B$ 's satisfaction, $B$ would probably have continued to use $S$ 's prodict and, therefore, her acquired knowhow. As a result of the breach, $B$ will probably be unable to deal with $S$ in the future, and lose the benefit of her experience. This loss is a noncompensable consequence of $S$ 's breach.

32. See Hadley v. Baxendale, 9 Ex. 341, 156 Eng. Rep. 145 (1854) (unforeseeable damages noncompensable); U.C.C. $\$ \S 2-714,-715$ (1977) (same); RESIATEMENT, supra note $5, \S 351$ (same).

33. The result would depend upon whether $S$ had actual knowledge of the fine provision in $B$ 's contract with $C$, or whether the term is usual in the trade. Compare Longview Constr. \& Dev. v. Loggins Constr. Co., 523 S.W.2d 771 (Tex. Civ. App. 1975) (subcontractor not informed of liquidated damages provision not liable for damages pursuant to this clause) with Krauss v. Greenbarg, 137 F.2d 569 (3d Cir.) (subcontractor informed of liquidated damages provision liable for damages pursuant to this clause), cert. denied, 320 U.S. 791 (1943). $S$ might well know about $B$ 's contract with $C$ and guess that $B$ will be late in delivering under it. $S$, however, might be unable to foresee that the delay will subject $B$ to a fine.

34. See, e.g., Chrysler Corp. v. E. Shavitz \& Sons, 536 F.2d 743 (7th Cir. 1976).

35. See E.A. FArNSWORTh, supra note $17, \S 12.15$, at 881 .

36. For a discussion of these informational losses, see supra note 31 .

37. This analysis assumes that $B$ is certain that she will prevail. If not, the uncertainty of recovery is another element of $B$ 's cost in pursuing the litigation route. $B$ does receive, however, the gain of sending a message to suppliers that she will not be an easy target.

38. Delay costs may be awarded in a suit for specific performance, at the court's discretion, without regard to foresecability. But delay damages are usually confined to well documented and easily determinable losses. See, e.g., Reis v. Sparks, 547 F.2d 236 (4th Cir. 1976) (increased closing and mortgage costs); Meyer v. Benko, 55 Cal. App. 3d 937, 127 Cal. Rptr. 846 (1976) (fair rental value of real estate). Losses attributable to damage to customer goodwill and the resultant losses of future dealings are likely to be too speculative to allow recovery. 
vantages in dealing with $S$ rather than a new supplier. As in the suit for damages, $B$ will have to bear most of her own litigation costs. In this case, the litigation costs are likely to be greater since $B$ will have to prove the additional element of inadequacy to justify specific performance. $B$ will have to show that the delay makes damages inadequate. ${ }^{39}$ Because substitute parts were probably available on the market before the completion of litigation, this is not likely to be a winning argument. In addition, the delay in performance will combine with the uncertainty of receiving an award of specific performance and place $B$ in a quandary: $B$ will, of course, receive damages in the event that she is not awarded specific performance, but she will not receive recompense for damages she could have avoided by arranging a substitute transaction. ${ }^{40}$

The option of suing for specific performance is thus untenable where there is a significant delay in litigation. The option is even less attractive if there is significant doubt whether specific performance is available. If $B$ fails to arrange a substitute transaction, she may be denied specific performance and only awarded damages as if a substitute performance had occurred.

\section{B Consents to the Modification, Receives Performance and then Contests}

By choosing this route, $B$ will be able to perform her contract with $C$ on time and avoid delay costs. $B$ will also retain the benefit of her experience with $S$ 's goods for the current contract with $S$. However, she will lose the opportunity to enter into future contracts since $B$ 's decision to sue will probably sour her relationship with $S . B$ might also have to pay the higher price for the goods, at least temporarily, ${ }^{41}$ thus losing the use of her capital and suffering the consequent opportunity costs.

Again, $B$ will bear most of her own litigation costs. Whether these costs will be greater or less than those in a damage action will depend upon differences in the burden of proof and standards of enforceability. $B$ 's costs for contesting the modification are likely to be lower because $S$ probably will have the burden of proving the enforceability of the modification. ${ }^{42} B$

39. Parts were available from reputable suppliers, but with a delay. $B$ must either argue that the delay creates market scarcity and therefore inability to cover, U.C.C. $\$ 2-716$ comment 2 (1977), or argue that her preference to deal with $S$ is sufficient to make the measure of damages uncertain or the parts unique. The latter argument is unlikely to succeed since $B$ is relying on relational elements to argue that an otherwise fungible product is in fact unique.

40. If the parts are not sufficiently scarce or unique to warrant specific performance, $B$ 's damages are measured by calculating the difference between the market price at breach and the contract price, U.C.C. \$ 2-713 (1977), and then adding any consequential damages incident to the cover remedy. This is an aspect of the mitigation doctrine which disallows damages avoidable by the breachedagainst party. Resrairimenr, supra note $5, \S 300$ (1).

41. $S$ might insist that $B$ prepay. If so, and the court applies the higher standard of duress, $B$ takes greater risk of being stuck with the higher price. See supra note 30 .

42. Generally, the party seeking to enforce the modification bears the burden of proving its en- 
will also face uncertainty as to whether the modification will be found enforceable and the risk that she will be stuck with the higher cost. This risk depends upon the standards for the enforceability of modifications.

The option of modifying the contract and contesting it after receipt of the return performance therefore gives $B$ all the advantages of receiving specific performance, without most of the delay costs of that remedy. $B$ will receive the promised performance in time to avoid any consequential damages, most of which are noncompensable under both the damage and specific performance remedies. These advantages are offset by the risk that the modification will be enforced. If the standards for enforceability of modifications are different from those for the award of specific performance, $B$ may be able to award herself an inexpensive remedy of specific performance where it normally would be unavailable.

\section{B Consents to the Modification}

If $B$ consents to the modification, she will receive the contract goods on time and avoid losses caused by delay. $B$ will be able to perform her contract with $C$, avoid the fine and maintain her relationship with her customer. In addition, this is the only route by which $B$ can preserve her relationship with $S$. Of course $B$ will pay more for the goods. Moreover $S$, and possibly other suppliers, aware of $B$ 's acquiescence, might be more prone to hold $B$ up in the future.

\section{B. Modification and Specific Performance}

The previous discussion demonstrates that the damage remedy severely undercompensates $B$. Specific performance, where available, results in more complete, but not full, compensation. Moreover, neither remedy is free from the problems of delay caused by litigation. Giving $B$ the ability to modify, receive performance and then contest the modification allows her to receive specific performance, but with the risk of possibly paying the modified price. If the standards for awarding specific performance were identical with those used for testing the unenforceability of modifications, the modification route would be more favorable to $B$ since adjudication delays would be avoided. In fact, the standards for the two remedies are quite different. As the following comparison of the standards for the two remedies shows, $B$ will often be able to contest a modification successfully where she could not obtain specific performance.

forceability. See, e.g., Roth Steel Prods. v. Sharon Steel Corp., 705 F.2d 134, 146 (6th Cir. 1983); Hillman, supra note 12, at 861 . Thus, $S$ would have to show that the modification was fair and made for a legitimate commercial reason. See infra notes 64-70 and accompanying text. In this case, neither element is present. 


\section{Specific Performance}

Specific performance is considered an extraordinary remedy, available at the discretion of the court" only when the damage remedy is "inadequate."' $\mathrm{Few}$ inadequacies in the damage remedy are considered legally inadequate. The most common legal inadequacy is that an award of damages is not sufficient to arrange a substitute transaction for obtaining the contract goods. ${ }^{45} \mathrm{~A}$ key factor in making this determination is whether a market in fungible goods exists; traditionally, the court has inquired whether the goods are unique. Uniqueness is presumptively present where the contract involves land, ${ }^{48}$ works of art and objects of sentimental value. $^{47}$ It - is occasionally, but rarely, found in commercial goods. ${ }^{48}$

A second legal inadequacy arises where the amount of damages caused by the breach cannot be determined. This reason is often intertwined with uniqueness: Where there is a market for the contract goods, the amount of damages is easily ascertained from the market price.99 Finally, the threatened insolvency of the breaching party may justify an award of spe-

43. RrsiatrimtiNr, supra note 5, § 357(1); U.C.C. § 2-716 comment 1 (1977).

44. Resin'timeini, supra note $5, \S 359(1)$. While the U.C.C. does not specifically. mention "inadequacy," it still limits specific performance to circumstances in which goods are unique and cover is unavailable. "The Code does not reject the adequacy test, and specific performance remains the exception rather than the rule under contracts for the sale of goods. If the seller fails to deliver the goods, the typical buyer must still content himself with money as a substitute." E.A. FARNSwORTH, supra note $17, \S 12.6$, at $830-31$.

45. See RrsiatrmeNT, supra note 5, § 360(b); U.C.C. § 2-716 comment 2 (1977).

46. Traditionally, each parcel of land was considered to be unique and its value therefore speculative. Thus, both buyer and seller were entitled to specific performance of a contract for the sale of land (buyer because of the unavailability of identical goods, seller because his damages were uncertain). This special historical status for land has persisted. See, e.g., ResratemENT, supra note 5, $\S 360$ comment $c$.

47. Heirlooms are the classic example of goods with sentimental value. Few contract goods would be able to sustain a claim of sentimental value. However, specific performance may occasionally be awarded if plaintiff can show that she expended effort to personalize the goods. See, e.g., Morris v. Sparrow, 225 Ark. 1019, 1020, 287 S.W.2d 583, 585 (1956) (specific performance of contract for sale of horse appropriate when horse has unique value).

48. The Restatement suggests, for example, that sales of stock in small corporations or assignments of patent rights might qualify. See R\&srairmint, supra note $5, \S 360$ illustrations 7 \& 8 .

49. The Restatement suggests that works of art and objects with sentimental value are items for which the damage remedy is uncertain. See id. $\$ 360$ comment b.

Output and requirements contracts are properly in this category because the amount of contract goods at stake is uncertain. But few examples of specific performance actually exist. In the case of requirements contracts, it would appear that the tests of uniqueness and market unavailability must be met; otherwise a damage figure could be determined from the going price for a replacement contract for the remaining term. See U.C.C. \$ $2-716$ comment 2 (1977); see also Laclede Gas Co. v. Amoco Oil Co., 522 F.2d 33 (8th Cir. 1975) (scarcity combined with public interest in fuel supply contract to justify specific performance); Eastern Rolling Mill Co. v. Michlovitz, 157 Md. 51, 145 A. 378 (1929) (court awards specific performance on output contract for scrap metal but defines composition of scrap "unique" rather than relying on uncertainty of profit alone). But see Hunt Foods Inc. v. O'Disho, 98 F. Supp. 267 (N.D. Cal. 1951) (fact that output contract runs over long-term sufficient to compel specific enforcement). On the whole, the enforcement of long-term contracts should be unaffected by the suggestions in this Article because modifications to them should pass the "unexpected circumstances" test. The only issue which might defeat the enforcement of modifications in such contracts would be a determination that the modified price is "unfair." See infra notes 68-69 and accompanying text. 
cific performance; an uncollectable award of damages is considered inadequate. ${ }^{\text {so }}$

The instances in which specific performance may be granted, especially in commercial settings, are therefore few. With only occasional exceptions, specific performance is unobtainable when markets exist in the contract goods, even when those markets are plagued by scarcity. The Uniform Commercial Code (U.C.C.), in commentary, suggests that a more liberal attitude toward awarding specific performance is in order, ${ }^{51}$ and specifically that "inability to cover" and scarcity of the contract goods should justify a decree of specific performance. ${ }^{32}$ But the text of the U.C.C. enumerates only uniqueness and "other proper circumstances." ful that these suggestions alone will induce courts to be more generous in awarding specific performance. ${ }^{54}$

Even where the inadequacy test is met, availability of specific performance is limited further by restrictions based upon the uncertainty of the terms of the initial contract, the courts' inability to supervise performance and public policy considerations.

Specific performance is unavailable where the contract does not describe the required performance with definiteness sufficient to frame an order. An agreement to build a "first class theater" cannot be specifically enforced, although damages may be awarded for its breach. ${ }^{\mathrm{ss}}$ Nor will specific performance be decreed if the burden of its supervision is onerous. This role denies specific performance in many cases of personal service ${ }^{57}$ and building contracts.

Promises to render personal service will usually not be specifically enforced. This reluctance is caused by the problems of supervision, the public policy against involuntary servitude, and the fact that performance of personal service contracts usually involves an intimate relationship between the parties, which makes enforcement of performance inappropriate

50. See Rrstatrimint, supra note $5, \S 360(3)$.

51. U.C.C. \$2-716 comment 1 (1977).

52. Id. comment 2 .

53. Id. $\S 2-716(1)$.

54. Courts have not, in general, availed themselves of the U.C.C.'s invitation to be more liberal. See Schmitt \& Pasterczyk, Specific Performance Under the Uniform Commercial Code-Will Liberalism Prevail?, 26 DePaul L. Rev. 54 (1976).

55. Bettancourt v. Gilroy Theatre Co., 120 Cal. App. 2d 364, 261 P.2d 351 (1953).

56. See, e.g., Restatriment, supra note $5, \S 366$. Difficulty of supervision is one element a court must weigh in deciding whether to grant specific performance. The court may therefore balance the need for the remedy against the anticipated burden. Courts are frequently unwilling to undertake long-term supervision of substantial projects-building contracts for example-absent extreme circumstances.

57. It is often difficult to determine whether a personal service contract has been satisfactorily performed. Consider, for example, the difficulty of determining whether Placido Domingo adequately complied with an order to perform Otello.

The public policy against involuntary servitude also contributes to the reluctance to compel performance of personal service contracts. This concern is far from compelling in most instances in which the initial agreement is consensual. See infra notes 145-49 and accompanying text. 
once the relationship has soured. ${ }^{\text {ss }}$ Finally, courts may refuse specific performance where a contract's terms, or the conditions under which the contract was entered into, render such enforcement unfair. ${ }^{50}$

\section{Modification Under the U.C.C.}

What are the standards for challenging a modification after receiving performance? The remainder of Section I first examines the requirements for sales of goods under the U.C.C. and then examines the requirements generally applicable under the Restatement (Second) of Contracts. Under both the U.G.G. and the Restatement, the standards for challenging the enforceability of a modification differ from-and are much easier to satisfy than-those which govern the availability of specific performance, both in terms of substantive criteria and burden of proof.

The U.C.C. appears to simply abolish the requirement of consideration for modifications. ${ }^{\circ 0}$ This might suggest that all modifications that do not run afoul of the laws of duress ${ }^{81}$ are enforceable. Few modifications would be defeated under traditional duress scrutiny. ${ }^{82}$ But the matter is compli-

58. See Restartimivr, supra note $5, \S 367(1)$ comments a \& b.

59. Id. $\S 364(1)$.

60. U.C.C. \$ 2-209(1) (1977). Nlthough the U.C.C., contrary to the Restatement, see REsTATEMENT, supra note $5, \S \S 73,75$, does not explicitly separate modifications supported by consideration from those that are not, policing modifications supported by consideration would face serious conceptual problems under both systems. How should one deal with contracting parties who agree to different, or additional, rights and obligations midstream? On the one hand, people should be free to agree to a second set of obligations and set their own price. On the other hand, mutual adjustments are prone to the same types of opportunism inherent in modification on one side alone.

Under traditional analysis, the policing of the fairness of a new exchange of obligations is complicated by the fact that the court has no benchmark for the value the parties would have set upon the exchanged, modified performances absent opportunism. Thus, under the Restatement, modifications supported by consideration can be challenged if the exchange is a pretense, REsTaTemENT, supra note $5, \S 175$, but not on the grounds of inadequacy of consideration. In theory, in the case of a unilateral modification, the court has a benchmark, the original unmodified price. But the original price is as poor an indicator of the value the parties initially would have set for the modified performance as none at all where "unanticipated" circumstances prompt the modification.

61. Gaps in the U.C.C. are to be filled by invocation of the underlying common law. U.C.C. \$ 1$103(1977)$.

62. To void a modification for duress, a promisee would have to demonstrate that the modification was secured by improper threat and that the promisee had no reasonable alternative but to agree. An improper threat requires that a promisor threaten more than a breach: The threat must amount to "a breach of the duty of good faith and fair dealing. . . "Resta TEMENT, supra note $5, \S 176(1)$ (d). While commentators suggest that any opportunistic threat of breach by a promisor would satisfy this requirement, scrutiny of the Restatement examples suggests that "improper threats" are those which link assent to a modification of one contract to performance of other, unrelated contracts. See RESTATEMFNT, supra note 5, $\S 176$ illustrations 9-11. Cases decided under duress standards appear to apply this higher standard of "wrongful threat." See, e.g., Austin Instrument, Inc. v. Loral Corp., 29 N.Y.2d 124, 272 N.E.2d 533, 324 N.Y.S.2d 22 (1971), a case much cited for the proposition that the doctrine of modification is governed by ideas of duress, in which the promisor links assent to a second contract with his willingness to continue with the contract at issue. I am unconvinced that Austin stands for any such proposition: In Austin, plaintiff was seeking restitution of excess payments made under the modified contract, and not simply contesting the enforceability of the modification. Under these circumstances, traditional doctrine requires the application of the doctrine of duress, see supra note 30 , which is precisely what the court did. 
cated by the fact that the comments to U.C.C. $\S 2-209$ suggest that modifications must meet the test of "good faith."

While the U.C.C. is not explicit on this issue, courts and commentators usually assume that the promisor, the party attempting to enforce a modification, has the burden of proof as to the contract's enforceability. ${ }^{64}$ The promisor, therefore, must demonstrate that the modification was made in good faith. Good faith requires that the modification be made only for legitimate commercial reasons. Between merchants, a legitimate commercial reason includes "observance of reasonable commercial standards of fair dealing in the trade," tively demonstrable reason . . . " "88 A legitimate commercial reason generally encompasses such factors as significant changes in the market for the goods or increases in the price of the promisor's inputs. ${ }^{67}$

The U.C.C. is unclear as to whether the price set in the modification must be scrutinized for fairness. Some commentators suggest that the good faith requirement should extend to the additional price: A modification cannot be in good faith if the amount of additional payments grossly exceeds the increase justified by the seller's legitimate commercial reason. ${ }^{88}$

Thus, the U.C.C. appears to suggest that the enforceability of the modification is purely a function of the circumstances which triggered the demand and the fairness of the modification. It would appear, therefore, that if the party seeking to enforce the modification cannot offer a legitimate commercial reason, the modification will be unenforceable. Similarly, a demand for more than a fair price increase would by itself render the modification unenforceable. ${ }^{60}$ Unless a duty of good faith is imputed to the promisee, ${ }^{70}$ the U.C.C. appears to place no limit on the promisee's power to modify and contest. The U.C.C., in short, does not explicitly incorpo-

63. U.C.C. § 2-209 comment 2 (1977).

64. See supra note 42.

65. U.C.C. $\$ 2-103(1)(b)(1977)$. Some courts require, in addition to a legitimate and commercial reason, that the promisor meet an "honesty in fact" standard, that the promisor actually sought the modification for a legitimate commercial reason, rather than for other nefarious reasons. See Roth Steel Prods. v. Sharon Steel Corp., 705 F.2d 134, 146 (6th Cir. 1983). This requirement makes contesting modifications even easier for consenting promisees.

66. U.C.C. § 2-209 comment 2 (1977) (citation omitted).

67. Usually, the promisor must be threatened with a loss if he performs as originally promised, see U.C.C. $\$ 2-209$ comment 2 (1977); J. Whrre \& R. Summers, supra note 1, at 48, or his conditions must change in a manner outside his control, T. \& S. Brass \& Bronze Works v. Pic-Air, Inc., 790 F.2d 1098, 1105 (4th Cir. 1986), to make the original performance very difficult.

68. See, e.g., Mather, supra note 12 , at 617 .

69. There is no suggestion that the court could, or would, reduce the price and enforce the modification. This reluctance is probably justified. An alternative rule would allow parties to try to maximize gains with no serious risk, while the current rule provides disincentives to negotiate high prices.

70. U.C.C. \$ 1-203 imposes a general obligation of good faith on performance or enforcement, and imposing such a good faith obligation on promisees seems well within its scope. Some courts have in fact done just this. Several cases interpreting U.C.C. \& 2-209 have scrutinized the good faith of the promisee, to see if she consented while never intending to honor the modification. See, e.g., United States ex rel. Crane Co. v. Progressive Enters., Inc., 19 U.C.C. Rep. Serv. (Callaghan) 1306 (E.D. Va. 1976). I suggest that a good faith inquiry is required to police promisee opportunism, but the standard of good faith should reflect the available legal remedy. 
rate any notion of promisee opportunism in its standards for the enforceability of modifications. This is equally true of the Restatement.

\section{Modification Under the Restatement}

The Restatement $t^{71}$ retains the common law requirement of consideration for modifications $\mathrm{s}^{\mathbf{2}}$ and states that modifications supported by consideration are enforceable unless the consideration is a "pretense"7s or the exchange is obtained by duress. ${ }^{74}$ In addition, modifications are enforceable if they are "fair and equitable in view of circumstances not anticipated by the parties when the contract was made . . ." While, as in the U.C.C., the Restatement does not explicitly allocate the burden of proof, again the promisor is usually assigned the burden, and he cannot enforce the modification unless he can demonstrate that it was a fair response to an unanticipated circumstance. The comments and illustrations emphasize that the unanticipated circumstances must be "objectively demonstrable"76 and that the increase in price not exceed additional costs imposed by the "unanticipated circumstance."

Thus, to be enforceable under the Restatement, modifications must meet stringent standards which are also purely a function of the circumstances which triggered the demand and the fairness of the additional price. The text does not explicitly limit the promisee's power to modify and contest, although Illustration 5 does suggest that, in order to defeat a modification, a promisee must show that she was forced to agree under protest because of delay problems in securing a substitute. Neither the Restatement nor the case law elaborates further on this limitation on promisee opportunism, but scholars have addressed the issue.

Most commentators have suggested that the inquiry on permissible modifications should focus on voluntariness, guided by standards governing invalidation of contracts on grounds of duress. ${ }^{78}$ In particular, most suggest that there should be some scrutiny of the promisee's alternatives to modification. But in developing this analysis, commentators, and the

71. While the Restatement does not in itself carry legal authority, its treatment of modification is an accurate formulation of the developing law of modification for contracts not governed by the U.C.C. See, e.g., Brian Const. \& Dev. Co. v. Brighenti, 176 Conn. 162, 169, 405 A.2d 72, 76 (1978) (citing Restatement as source of law applicable to contract modifications); Recker v. Gustafson, 279 N.W.2d 744, 758 (Iowa 1979) (citing Restatement for law applicable to modifications); Angel v. Murray, 322 A.2d 630, 636 (R.I. 1974) (Restatement reflects modern trends in modification law).

72. RFsis'remeNi, supra note $5, \S \S 73,75$.

73. Id. \$73. $\Lambda$ pretense of exchange can be very difficult to police, see supra note 60 .

74. Id. $\$ \S 175-76$.

75. Id. $\S 89$ (a).

76. Id. $\$ 89$ comment b.

77. Id. $\S 89$ (a) comment b, illustrations $1-5$. Some courts have allowed the modification price to include additional profit as well as unforeseen costs. See Brian Constr. \& Dev. Co., Inc. v. Brighenti, 176 Conn. 162, 165, 405 ^.2d 72, 74 (1978).

78. See, e.g., E.A. FARnSWOR'rH, supra note 17, § 4.22, at 278; Hillman, supra note 12, at 880-89. 
handful of courts which have incorporated it, have continued to view the promisor as the opportunist and the promisee as the victim. Significantly, all have accepted the argument that when the promisee demonstrates that the damage remedy is inadequate for full compensation, she has shown that she had no reasonable alternatives. ${ }^{79}$ Commentators, therefore, would allow the promisee to successfully contest the modification even if she would gain more by modifying and contesting than from a suit to enforce the original contract.

Thus, when $B$, in the example used in Section I-A, must choose either to refuse to modify and to sue for specific performance, or to agree to the modification with the intention of contesting, $B$ will find the latter alternative more attractive because of the delay problems inherent in the specific performance remedy. If the delay problem is not conclusive, however, $B$ will weigh the likelihood of receiving specific performance and its costs and benefits against the likelihood that the modification will be enforced, with its costs and benefits. In the typical situation, $B$ will discover that her ability to contest the modification is much greater than her ability to prevail in a suit for specific performance.

To be awarded specific performance, $B$ will have to show that damages are inadequate. As demonstrated above, this showing is a difficult task if a market exists in the contract goods. $B$ will either have to argue that the parts are so specialized that she cannot trust alternative suppliers, ${ }^{80}$ or that the delay in arranging an adequate substitute performance constitutes a proper circumstance ${ }^{81}$ justifying specific performance. In the abstract, the U.C.C. might well contemplate broad categories within which specific

79. Several commentators, while suggesting that the requirement that the promisee have no reasonable alternatives be imputed, offer no guidance as to the requirement's content beyond a general analogy to the laws of duress. See, e.g., E.A. FARNSWORTH, supra note 17, § 4.22, at 278.

Others would impose some burden on the consenting party, but explicitly consider the alternative of damages to be an unreasonable alternative. Muris suggests that modifications made in the absence of unanticipated circumstances should not be enforced if the modifying party fails to show that the consenting party had no lower cost alternative to the modification. In making this determination, the undercompensatory nature of the damage remedy is to be considered a cost of the damage route:

Of course, this 'reasonable alternative' device probably has somewhat limited application in the modification context. . . . Litigation will often be more costly than the modification, given the ability of the promis[or] to increase the promis[e]'s expenses and the failure of the law to provide for compensation of litigation expenses and for certain types of damages.

Muris, supra note 1, at 545. See also Hillman, supra note 12, at 891-92 (Substitute transaction considered reasonable alternative to agreeing to modification only if it is priced close to original contract price. Otherwise, "the injured seller or buyer is dependent on the remedies system to make him or her whole. Because of the weakness of the contract remedies system, however, seeking judicial relief generally should not be treated as a viable choice.") (citations omitted). Professor Hillman suggests that Pirrone v. Monarch Wine Co., 497 F.2d 25 (5th Cir. 1974) is a good illustration of the inadequacy of judicial relief in the modification context because Pirrone's alternatives would have resulted in non-compensable damages including litigation costs and those damages were unforesceable to Monarch. Id. at 892 \& n.192.

80. This is, in effect, an argument that the goods are unique. This argument is frequently found in the rare cases where specific performance is awarded in market situations. See, e.g., Eastern Rolling Mill Co. v. Michlovitz, 157 Md. 51, 145 A. 378 (1929).

81. U.C.C. § 2-716(1) (1977). See supra notes 58-59 and accompanying text. 
performance may be awarded. But the contention that a delay of a few weeks is sufficient to allow a finding of market scarcity is probably implausible; courts have been quite reluctant to broaden the ambit of specific performance to market goods. Moreover, since the delay in adjudication is likely to provide adequate time for $B$ to obtain a substitute performance, $S$ will be able to argue that some of $B$ 's delay damages were mitigable by cover and should not be compensable. ${ }^{82}$ To counter this argument $B$ must then argue that the parts were unique because her relationship with $S$ had given her a special insight into the parts. Where the parts appear to be fungible, this argument is unlikely to prevail. ${ }^{83}$ Nor are other justifications for specific performance-damages difficult to prove ${ }^{84}$ and of idiosyncratic value ${ }^{88}$ - present. $B$ almost certainly will not prevail in a quest for specific performance.

If $B$ consents to the modification, however, and then refuses to pay, $S$ will have to convince the court that the modification was justified by an objective commercial reason, and that the modification was fair. On the given facts, $S$ will not sustain this burden. Nothing suggests that an external event was at the root of $S$ 's demand for a price increase. Nor is the price fair as either a cost increase caused by an increase in costs to $S$ or as the price charged by like suppliers for like services. As indicated above, ${ }^{\mathbf{8 6}}$ the modification would therefore be unenforceable under the U.C.C. $S$, then, will be unable to recover more than the initial contract price for the parts. $B$ will, in effect, have decreed specific performance for herself at no increase in price.

\section{Revising The Scope of the Self-Help Specific PERFORMANCE REMEDY}

\section{A. The Specific Performance/Damages Debate}

To what extent can a self-help remedy of specific performance be justified? The answer to this question must be preceded by an inquiry into the role of specific performance in the law of remedies for breach of contract. Where specific performance better furthers the goals of contract enforce-

82. This argument suggests that it is inadvisable to extend the specific performance remedy this far if the remedy is to remain extraordinary. The availability of specific performance in this case will lead to inefficiencies: If $B$ is able to recover for these damages, $B$ has no incentive to reduce the consequences of the breach. If the court awards specific performance but not these delay damages, specific performance is an unattractive remedy for $B$.

83. $B$ might try to use Austin Instrument, Inc. v. Loral Corp., 29 N.Y.2d 124, 272 N.E.2d 533, 324 N.Y.S.2d 22 (1971), to argue that the goods are unique if the parts are complicated electronic components or similar goods.

84. See supra note 49 and accompanying text. This argument is plausible when plaintiff is a buyer who uses the parts in manufacturing her own product because her major loss is likely to be lost opportunities, which are usually impossible to evaluate. The rationale that damages are highly uncertain is rarely used in this context, however, and damages remain the preferred remedy.

85. See supra notes $46-47$ and accompanying text.

86. See supra notes $65-70$ and accompanying text. 
ment than does the damage remedy, this advantage must be weighed against the potential for opportunism created by the disparity in value between the self-help and legal remedies. This section first examines the ongoing scholarly debate over whether specific performance should supplant damages as the preferred remedy in contract law. It concludes that the merits of the former over the latter are not clear in the majority of cases. This conclusion informs the final section, which argues for a selfhelp remedy of clearly defined scope.

A number of legal commentators argue that specific performance should be the preferred remedy for breach of contract. ${ }^{87}$ They maintain that the damage remedy does not fully compensate a promisee because subjective and unforeseeable elements of damage are non-compensable. ${ }^{88}$ Thus, contracting parties face non-compensable losses upon breach, and are susceptible to opportunistic behavior by their partners.

The specific performance remedy assures a promisee of receiving the promised performance, with all of its subjective and unforeseeable elements of value. The promisee is still undercompensated because she cannot recover litigation costs, ${ }^{89}$ but the losses incurred by the promisee upon breach and the frequency of breach will be greatly reduced. Moreover, if transaction costs are ignored, the breach decision will be efficient. ${ }^{90}$ The cost of breach is clearly defined to the potential breacher-the cost of his performance. Specific performance, then, ensures full compensation without decreasing the efficiency of the legal rule. ${ }^{21}$

The transaction costs associated with the two rules, however, are quite different. Defenders of the preference for the damage remedy over specific performance contend that a specific performance rule will increase transaction costs. Specific performance gives the promisee a credible hold-up threat, because it obliges the promisor to negotiate with the promisee when the former finds a profitable substitute transaction. Thus, promisors in competitive markets would prefer to retain the right to accept better offers and pay damages. Since cover is available, promisees would be indifferent to the remedy. If specific performance were routinely awarded, costly resources would be expended in negotiating out of the specific per-

87. See, e.g., Schwartz, The Case for Specific Performance, 89 YAl.E L.J. 271 (1979).

88. See supra note 79 and accompanying text.

89. Even if the legal remedy allowed a promisee to recover fees, she would still incur all the costs of delay, and loss of relation-specific values. See supra notes 38-40 and accompanying text. The availability of specific performance should, however, reduce the probability of breach because the promisor will have less value to exploit.

90. If transaction costs are ignored, both the damage rule and specific performance lead to efficient breach decisions, and differ only in the distribution of gains incident upon breach. See, e.g., Macneil, Efficient Breach of Contract: Circles in the Shy, 68 VA. L. Rkv. 947, 950-53 (1982).

91. Specific performance will still not result in full compensation. Plaintiff will still incur both litigation and delay costs. The general availability of specific performance will, however, probably result in fewer breaches. 
formance remedy. In contracts involving non-competitive goods, however, promisees would prefer a remedy of specific performance.

Current legal remedies provide promisees with damages in market cases and reserve specific performance for transactions involving unique goods. Defenders of the current rule argue that this is more efficient than a general specific performance rule because it reduces the cost of contracting. ${ }^{92}$

Professor Schwartz, however, suggests that neither of these arguments is valid in a competitive market. Costly negotiations between a promisor and a promisee would not occur, since a promisor could also purchase substitutes on the market and perform his contract. ${ }^{93}$ Similarly, contracting parties would be less concerned ex ante about the specific performance remedy as they can anticipate price fluctuations from market data available at the time of contracting. Thus, Professor Schwartz argues, since specific performance fosters full compensation for breach, and its presumed inefficiencies are non-existent, it should be the preferred remedy for breach.

The problem with Schwartz's argument, however, is that in a truly fungible market, specific performance has no particular advantages. If the promisor can cover and perform, so can the promisee. ${ }^{94}$ Only when performance diverges from the purely fungible market performance do transaction costs of the specific performance rule increase. ${ }^{95}$

The choice between specific performance and the damage remedy is no more obvious on moral grounds. While it is arguably appropriate that the promisee receive what she has been promised and that the promisor carry out his promise, ${ }^{98}$ the scope of the moral justification for any remedy depends upon what has been promised. To the extent that the negotiating parties know, or should know, the damage rules at the time of contracting, the scope of a promisor's obligation must be measured not only by his promise, but also by the remedies for its breach.

It is beyond the scope of this Article to explore more fully the relative advantages of the damage and specific performance remedies. Indeed, Professor Macneil has recently argued that the relative advantages of the two remedy systems cannot be determined without a much more detailed elaboration of transaction costs. ${ }^{97}$ What is clear is that the question presents complex issues, which have yet to be definitively answered.

92. See, e.g., Kronman, Specific Performance, 45 U. CHI. L. Rev. 351, 365-69 (1978).

93. Schwartz, supra note 87 , at 284-91.

94. If specific performance is the rule, however, the promisor is more likely to choose performance over breach. If he does, delay and litigation costs may be avoided, and contractual relationships maintained.

95. See Goetz \& Scout, The Mitigation Principle: Toward a General Theory of Contractual Obligation, 69 VA. L. Rev. 967,988 \& n.49 (1983).

96. Professor Linzer convincingly argues for specific performance for legally naive parties, who are unaware of the legal consequences of breach when they contract. See Linzer, supra note 19, at 116-17.

97. See Macneil, supra note 90, at 954-60. Transaction costs described by Macneil include: pre- 
Given the underlying uncertainty as to the optimal remedy for breach of contract, it is unwise to allow one party, threatened with breach, to circumvent the damage remedy by the indirect route of the modification doctrine. At best, this doctrine gives the contracting parties yet another device for opportunistic manipulation. If the inadequacy of damages is a potential weapon that one party can manipulate to its advantage, ${ }^{88}$ the current modification doctrine is an equivalent weapon that the other party may use to circumvent the legal standards of remedy.

Self-help specific performance cannot generally be justified as a corrective for promisor opportunism. Self-help specific performance imposes much higher costs on a promisor than does the damage remedy. If a promisor attempts to increase the contract price to reflect the cost of the self-help remedy, however, the parties will face significant difficulties in negotiating the price. The promisee might well be unwilling to include the price of self-help specific performance, as the right must be triggered by the promisor. The promisee cannot take advantage of the self-help remedy unless the promisor demands a modification. ${ }^{99}$ Promisors will face an equally high degree of uncertainty-they will not know whether promisees will honor the modification. ${ }^{100}$ These uncertainties, generated by be-

breach negotiations and planning, searching, finding and negotiating the new opportunity, potential and actual litigation, information costs, costs of uncertainty, relational costs, costs of incria, and gains from legal rules which encourage communication between the parties and lead to mitigation of losses. Id. at 958 . He also alludes to the possibility of externalizing costs, such as escaping from the consequences of breach because of the American rule on attorneys' fees. Id. at 958-60. Macneil maintains that the ultimate resolution of the issue depends upon empirical evidence of transaction costs and externalities. The complexity of such analysis, he suggests, may not be worth the candle. He therefore suggests that it might be "far better to ignore all the sophistication in favor of historical or more intuitive solutions." Id. at 954 n.28.

98. See, e.g., Goetz \& Scott, Liquidated Damages, Penalties and the Just Compensation Principle: Some Notes on an Finforcement Model and a Theory of Efficient Breach, 77 Colum. L. REv. $554,569-76$ (1977).

As long as the damage remedy remains the preferred enforcement mechanism, the noncompensability of subjective elements of damage can be justified on several grounds. It has, for example, been defended on the grounds that the proof of subjective damages increases costs, and therefore is inefficient. Moreover, compensability of subjective and unforeseeable elements of damage increases the costs of contracting: Contracting parties would be unable to predict the value of the contract and the consequences of breach. Since promisors would be liable for an increased and unpredictable amount in the event of breach, they would likely want to be paid for the increased risk. Promisees, however, would be unwilling to shoulder this cost, as it is only valuable in the idiosyncratic case. Goetz \& Scott, supra note 95 , at 986 n.47.

Moreover, a rule of non-compensability places the burden on the party who will face idiosyncratic costs to identify those costs at the beginning of the relationship, allowing the parties to reach accurate pricing values, and to make efficient breach decisions. Id. at 986.

99. Promisors need not necessarily resort to breach: They might create "exchanges." See infra note 115 .

100. It is likely that if the price of the self-help remedy is included in the contract price, promisees will resort more frequently to that alternative. Promisees will feel morally justified in doing so if they feel that they have paid for it. But as the likelihood of resorting to self-help increases, promisors are less likely to give promisees the modification option unless they are reasonably confident that the modification is legally enforceable. Thus, promisees are likely to resist including the cost of the selfhelp remedy in the contract price. The difficulty of incorporating the cost of a potential self-help remedy into a contract illustrates that parties cannot correct for such problems of opportunism themselves without incurring significant costs. 
havior within the sole control of the parties, are extremely costly. Increased resort by promisees to the self-help route where damages are the normal remedy might well result in reduced willingness of promisors to offer promisees the option of modifying and receiving performance.

Just as it is ill-suited to counter promisor opportunism, the self-help route is not a suitable means to correct the laws of remedy-even where it is agreed that specific performance is the appropriate remedy. The mutual opportunism generated by the self-help approach is both random and costly. ${ }^{101}$ Although the current system of remedies may not lead to the most efficient allocation of contractual resources, current modification doctrine is no more likely to reach efficient results. The current remedy system allows the breaching party to ignore ${ }^{102}$ many of the costs imposed on the other party, thus increasing the likelihood that breach decisions will be inefficient. ${ }^{103}$ But under current modification doctrine, the consenting party is equally free to ignore the costs imposed on its partner by performance. A promisee must demonstrate that self-help specific performance is efficient for her-that the damage remedy will leave her with uncompensated losses. ${ }^{104}$ At no point does modification doctrine require that the costs to the promisor of performing be weighed against the gains of requiring the performance.

\section{B. The Proper Scope of Modification as a Self-Help Specific Perform- ance Remedy}

Modification doctrine should provide consenting parties with the same rights that they would be entitled to in the event of a breach, and should not be used to expand the substance of contract remedy. ${ }^{105}$ The self-help

101. This analysis raises the interesting possibility that, at least where contract law fails to prefer one remedy over another, remedies should be chosen to minimize opportunism. If minimizing the potential for opportunistic behavior is the determinant, specific performance might be appropriate in transactions where there is a strong likelihood that the parties will make investments, or generate skills, which can only be exploited by maintaining their relationship. See supra note 45 . This might be an additional argument for awarding specific performance for some long term output or requirements contracts. Further elaboration of these ideas, however, is beyond the scope of this paper.

102. The party can, as Professor Macneil views it, externalize the costs associated with breach. See Macneil, supra note 90 , at 960 .

103. $S$, in deciding whether to breach, will weigh his gains upon breach against the costs he will incur. $S$ need not consider costs, such as idiosyncratic or relational values, imposed upon $B$ for which $S$ would not be liable. As discussed earlier, it is not clear whether the damage rule leads overall to efficient or inefficient results, since the burden of identifying and bargaining over idiosyncratic values and unforesecable damages is placed on the party with better information and non-standard requirements. See supra notes 98-101 and accompanying text.

104. A promisee must, at most, demonstrate that she had no reasonable alternatives to self-help specific performance. As interpreted by the courts, she carries this burden by showing that the damage - or cover-remedy leaves her with uncompensated losses. See supra note 89 and accompanying text.

105. Contemporary modification doctrine assumes that only the party seeking to modify may act opportunistically. An exception to this rule is found in the cases that examine the "good faith" of the promisee. See supra note 70 . This view is justified only if one assumes that a promisor has an absolute obligation to perform and does not have the right to choose between performance and breach with 
modification route should be available only in situations where limits on judicial administration and competence frustrate the goals of contract law and consign the promisee to recognizably inadequate contract remedies. ${ }^{106}$

The promisee can demonstrate that her legal remedy is inadequate where: (1) she is entitled to specific performance because of the unavailability of a substitute, ${ }^{107}$ but this is not a practical option because of the delay in obtaining relief; ${ }^{108}$ or (2) specific performance is the appropriate remedy, but is nevertheless unavailable because courts are not capable of policing the administration of the remedy. ${ }^{100}$

In cases in the first category, where specific performance is available in a suit to enforce, the promisee is unable to act opportunistically, and the promisor's ability to manipulate the contract is limited by enabling the promisee to modify and contest after performance. ${ }^{110}$ In the second case,

the payment of damages. This assumption, however, is at odds with the underlying premises of contract doctrine, particularly the law of damages. That contract remedies are compensatory and not intended to induce performance, and that punitive sanctions are unavailable for breach, demonstrates an underlying philosophy of contract which views the obligation undertaken, and bargained for, as the choice between performance and breach with the payment of.damages. Indeed, contract law has gone even further. Contracting parties are generally forbidden from ensuring performance by imposing consensual liquidated damages clauses that "penalize" non-performance. See Goetz \& Scott, supra note 98.

The argument that the obligation undertaken in a contract is an obligation of performance, while provocative, is appropriate as a challenge to the underlying doctrine of contractual obligation, but is misplaced in a discussion concerning the scope of self-help possibilities inherent in a law of modification. It is also possible to favor modification as a back door used to correct deficiencies in the remedy system. This approach recognizes that modification leads to mutual opportunism, but tolerates it as a second-best solution to the problem of damage inadequacy. Again, I believe that, on the whole, the problem of opportunism is better attacked by changing the law of remedy.

106. $\Lambda$ greed upon remedies such as liquidated damages, which are designed to supplement inadequate legal remedies, should be routinely enforced, and even preferred in cases where no irregularities have surfaced in the bargaining process.

107. Specific performance also should be awarded because of scarcity or a standard of market unavailability required by the court.

108. See, e.g., Austin Instrument, Inc. v. Loral Corp., 29 N.Y.2d 124, 272 N.E.2d 533, 324 N.Y.S.2d 22 (1971). If the facts in United States ex rel. Crane v. Progressive Enters., 19 U.C.C. Rep. Serv. (Callaghan) 1306 (E.D. Va. 1976), were such that specific performance would have been granted, the modification should have been enforced. If the promisee's actions did not impose additional costs on the promisor (he would have had to perform in any event), the promisor should not be penalized for failing to "protest." One problem with decreeing specific performance is ensuring that the promisor will perform under compulsion in the same manner he would have if he had performed willingly. Where the promisee is not attempting to expand her rights, there seems little reason to insist that she compromise the performance due by instigating relational problems before performance takes place.

109. For example, in cases involving partially completed construction contracts, courts often agree that specific performance is the only appropriate remedy, but refuse to award this relief because they fear judicial involvement in the long-term policing of the performance. See infra notes 125-29.

Consider also contracts for personal services: for example, a promise by a famous singer to perform in a production. Courts refuse to award specific performance (although they might enjoin the singer from performing elsewhere) for two reasons: (1) the difficulty of determining satisfactory performance, especially under threat of contempt; and (2) fear that compelled personal services smack of involuntary servitude. As to the first reason, the problem of inducing a satisfactory performance is diminished when the performer was performing willingly before the relationship broke down. As to the second, the involuntary servitude argument is unconvincing when addressed to short-term, agreed upon performances. See infra notes $145-48$ and accompanying text.

110. If the promisor is aware of the modification rule, he knows that the promisee incurs no risk by modifying. This might make promisors disinclined to agree to modifications. The promisor, how- 
where specific performance is not available, a promisee can act strategically, increasing her returns by pursuing the self-help remedy. In so doing, promisees are getting more than they have paid for. ${ }^{111}$ This is tolerable because the additional rights promote contract goals better than currently is possible in the courts. ${ }^{112}$ Indeed, if the courts' ability to enforce specific performance were not limited, promisees would have the right to specific performance currently denied them. The contracts in this second category involve goods for which close market substitutes are either non-existent or not readily available. In these instances, parties should be willing to pay for the specific performance remedy. ${ }^{113}$ The probable reason that specific performance is not more frequently included in contracts is that contract clauses choosing specific performance are rarely enforced. ${ }^{114}$

The main problem with allowing promisees to pursue the self-help route in the second case is that, as promisors discover that such modifications are not enforceable, they will refuse to give promisees the choice between modification and breach. This will reduce a promisee's chances of

ever, has nothing to gain by refusing the modification, since he will be forced to perform the contract.

Promisors probably will attempt to convert their opportunistic potential by either modifying with consideration or entering into another contract with the promisee before completing performance on the first. Until it is possible to effectively police the entire spectrum of modification, including modifications with consideration and follow-up contracts, litte can be done to police truly unique (including relationally unique) services.

111. Since the promisor would have assumed that specific performance would not be decreed in these cases, the contract price will not include the cost of this right. I am assuming that, at the time of contracting, promisors are likely to know the costs of breach-the damage rules-but not the modification rule. $\Lambda s$ they recognize the implications of modification, promisors will try to include the price of the specific performance remedy in the contract. Promisees will resist because promisors will still have the option of breaching and paying damages. See infra note 115 and accompanying text. This analysis assumes that parties consider legal rules when they negotiate, and factor them into the contract price. This is by no means a non-controversial assumption. See, e.g., Macaulay, Non-Contractual Relations in Business: A Preliminary Study, 28 AM. Soc. Rrv. 55, 60 (1963). A great deal of contract scholarship, however, proceeds from the assumption that parties incorporate all legal rules into the contract price. See, e.g., Goetz \& Scott, supra note 95, at 971.

112. This assumes that parties are aware of remedies and factor them into the contract price. If these costs are not included, either the promisee's price will be too low, since it will reflect the assumption that damages are the likely remedy, or all prices will rise as the contracting parties factor the self-help remedy into the price. In the latter case, specific performance-with its associated costs-would have been the remedy of choice for a majority of actors; only administrative costs prevent specific performance from being the standard remedy for breach. See Kronman, supra note 92, at 365-69.

113. Id.

114. Id. at 370-72. Where specific performance is unavailable because of judicial incompetence in administering and enforcing the remedy, it is not surprising that a clause electing specific performance is unenforceable. The same problems in administering the remedy may be anticipated whether it is the remedy chosen by the partics, or is judicially imposed. Where the remedy is unenforceable because the parties have been unable to demonstrate that the damage remedy is inadequate, courts should uphold the specific performance clause. In this case, the parties have decided explicitly that the damage remedy is insufficient. It can be safely presumed that an increment in price was paid for this additional right. No rationale is served by refusing the parties the option of waiving the damage remedy. They have essentially self-identified a unique relationship, saving the costs and errors associated with an ex-post determination. If they impose no costs on the judicial system, their judgment should be honored. 
receiving performance. ${ }^{115}$ Thus, our long-term ability to police promisor opportunism is limited in cases where specific performance is essential but unavailable. In contracts involving non-fungible goods or services, the only way to deter promisor opportunism is to strictly enforce the specific performance remedy. ${ }^{110}$

The remainder of this section considers in detail the justifications for allowing a self-help right of specific performance in cases where a promisee can demonstrate that the contract goods or services are difficult to replace, hence exposing her to opportunistic behavior by the promisor. The section first examines cases where specific performance would be available in a suit to enforce the contract. The self-help remedy is generally justified in these cases. The section then addresses cases in which specific performance, while theoretically superior to enforce the contract, is judicially unavailable for discretionary reasons. Here, the reasons for the discretionary refusal to grant specific performance will determine the appropriateness of the self-help remedy.

\section{Damages Inadequate, Specific Performance Available}

Let us assume that buyer $(B)$ can demonstrate that the contract parts are highly specialized and that equivalent parts are so scarce that they must be considered unique. ${ }^{117} B$ is then entitled to receive specific performance. What are the relative positions of $B$ and seller $(S)$ when $S$ threatens to breach unless the contract is modified?

$S$ and $B$ know that there are limited substitutes for the contract goods. $B$ has a right to specific performance, the value of which should be reflected in the contract price. The monopolistic nature of this contract affords $S$ significant opportunity to exploit $B$. The potential for exploitation results from the cost of litigation, and any other costs imposed upon $B$ by delay. What is $B$ 's potential for exploiting $S$ ? By modifying the contract, receiving performance and then contesting the modification, $B$ would receive no more than she would have received by suing for breach, and no more than was her due under the contract. ${ }^{118} B$ will receive a real-if

115. In this case, opportunism cannot be eliminated by the judicial system. This has led one commentator to suggest that such modifications be enforced. See Robison, Enforcing Extorted Contract Modifications, 68 Iow A L. REv. 699, 739 (1983). I believe that, instead of abandoning performance, promisors will in all likelihood resort to creative strategies to create exchanges rather than modifications. For example, a promisor might agree to do more than originally required, at a price which would include a premium for the original performance. Such an agreement would be very hard to police. See supra note 60 .

116. Professor Schwartz argues that in many cases where specific performance is refused for administrative reasons, the problem might be solved by appointing special masters to oversee the contract's performance. See Schwartz, supra note 87, at 293-94.

117. See Austin Instrument, Inc. v. Loral Corp., 29 N.Y.2d 124, 272 N.E.2d 533, 324 N.Y.S.2d 22 (1971).

118. $B$ might not avoid much in the way of litigation costs either. If $S$ is sure that the attempt to enforce the modification will fail, $S$ might not sue and $B$ will avoid litigation costs. This is the least costly way to achieve the remedy system's objective of giving $B$ performance. $S$ might still sue for 
intangible-benefit by pursuing self-help: Under the modification route, $S$ performs willingly. If specific performance is judicially decreed, $S$ 's performance would be compelled. $S$ 's performance in the former case is likely to be superior to that in the latter. ${ }^{119} B$ would also avoid the delay of judicially-decreed specific performance. Where these delays are so extreme that $B$ would be deterred from suing for specific performance, $B$ will convert a theoretical right to specific performance into a real one through the self-help remedy.

Where $B$ has a right to specific performance, ${ }^{120} S$ may use potential litigation costs, time pressures, and the threat that specifically decreed work will be poorly performed to exploit his contractual relationship with $B$. $B$, however, can never receive more than her contractual rights. Under these circumstances, a rule allowing $B$ to modify the contract and contest the modification after performance will not result in exploitation of the relationship by $B{ }^{121}$ Rather, the self-help remedy limits $S$ 's opportunistic potential.

Will such a rule make $S$ less willing to modify contracts and more likely to breach? If $S$ suspects that the modification cannot be enforced, and therefore decides to breach, $B$ may be unable to induce $S$ to perform, no matter how great her need for performance. On the other hand, if $S$ insists upon breaching, he will still be required to perform, with the additional possibility of paying delay damages. The risks to $S$ of both the breach and modification are identical and will be determined by the likelihood that specific performance will be decreed. ${ }^{122} S$ therefore has nothing to gain by breaching. Indeed, $S$ can only receive additional payment by retaining his relationship with $B$, in the hope that $B$ will honor the modification. This incentive might induce $S$ to make reasonable demands.

Once $B$ has demonstrated that she is entitled to specific performance

enforcement of the modification, in the hope that $B$ will negotiate a settlement to avoid litigation costs, including the cost of proving that she would have been entitled to specific performance. The alternative of suing for specific performance after $S$ has threatened to breach is unlikely to be lower in cost, even where delay is not costly, as $\boldsymbol{S}$ has already indicated willingness to engage in strategic behavior.

119. Even mundane obligations can be performed with varying degrees of success. $\Lambda s$ the quality of performance becomes more important, the significance of receiving a willing performance rather than coerced compliance increases. See Macneil, supra note 90 , at 951 n.19.

120. To some extent, specific performance is never available as a matter of right, since it is a discretionary remedy. Nevertheless, the threshold requirements for receiving specific performance are governed by well-defined rules. Courts will only exercise discretion to award specific performance in cases where the damage remedy is inadequate. In many such instances, I suggest that a self-help remedy should be available.

121. This inducement may, however, encourage less than economically optimal results because $B$ can induce $S$ to perform by promising $S$ a higher price than $B$ will actually pay. If $S$ could find a suitable substitute for $B$ at a lower price than his own performance, $S$ has no incentive to do so if he believes that he will be paid the modified price for his performance. In most cases this problem will not be significant: For this problem to occur, $S$ must be able to find a substitute performance, while $B$ cannot. A similar, but more significant, difficulty occurs in the cost-of-completion problem discussed infra note 125 .

122. This assumes that courts will apply the same standards after the self-help remedy has occurred as they will when plaintiff sues for specific performance. 
under the original contract, nothing further should be required to find the modification unenforceable. ${ }^{123}$ Specifically, $B$ should not be required to show that self-help was essential and the legal avenue for redress inadequate because of time pressure. ${ }^{\mathbf{1 2 4}}$ Once it is determined that specific performance would have been decreed, nothing is gained by imposing additional burdens of proof.

\section{Damages Inadequate, Specific Performance Unavailable for Dis- cretionary Reasons}

Even where the promisee can show that the damage remedy is inadequate, and that an award of specific performance is therefore justified, courts often refuse to grant this extraordinary remedy for a variety of discretionary reasons. These reasons are of two types. The first group of reasons considers limitations of the judicial administration system. The second group of reasons addresses considerations of public policy or fairness.

\section{a. Specific Performance Unavailable Because of Inadequacies in Ju- dicial Administration}

A court's decree of specific performance requires a party to perform the actions required in the order under threat of contempt. The issuing court must police execution of the judgment. The court must supervise and evaluate the performance. For this reason, courts often refuse to grant specific performance of long-term contracts and contracts that require subjective judgments as to the quality of the performance. ${ }^{125}$ Specific performance

123. As a matter of policing promisee opportunism, the demonstration of entitlement to the remedy should end further inquiry. The modification might, of course, be enforceable because it satisfies all requirements aimed al policing promisor opportunism, such as being a fair and equitable response to changed circumstances.

124. There is some confusion in modification doctrine over the significance of the availability of specific performance. To the extent that specific performance has been explicitly considered in modification cases, where the court has required $B$ to demonstrate that she had "no reasonable alternatives" to the modification, the availability of a suit for specific performance has been deemed such an alternative. Thus the availability of specific performance has been used to undercut a promisee's ability to contest modifications. See United States ex rel. Crane Co. v. Progressive Enters., 19 U.C.C. Rep. Serv. (Callaghan) 1306, 1309 (E.D. Va. 1976). Commentators have criticized this reasoning because the remedy is uncertain and, even if available, untimely. See Hillman, supra note 12, at 872.

Where the alternative of the legal remedy has been ignored, courts have focused on the uniqueness of the contract goods to justify finding that the promisee agreed to the modification because she had no reasonable alternative. See, e.g., Hillman, Contract Modification in Iowa-Recker v. Gustafson and the Resurrection of the Preexisting Duty Doctrine, 65 Iowa L. Rev. 343, 361 (1980) (since land is "considered unique," defendant had no reasonable alternative but to agree to modification).

125. See supra notes 56-57 and accompanying text. Proponents of a blanket specific performance remedy suggest that, where the court is reluctant to decree specific performance because of the burden of supervision, that burden may be reduced by appointing special masters. Judicial costs increase when specific performance is awarded. These additional costs, however, may be justified by the increase in efficiency derived by granting specific performance instead of damages. See Schwartz, supra note 87 , at $291-92$.

The court's reluctance to oversee the completion of construction contracts is probably the rationale 
will also be refused if the performance due under the contract is not clearly defined. ${ }^{126}$ This refusal reflects courts' reluctance ${ }^{\mathbf{1 2 7}}$ to force parties to perform actions under the threat of contempt where the scope of the required performance is uncertain.

When the limits of judicial administration prevent a promisee from receiving an otherwise justified award of specific performance, she should be able to modify, receive the contractual performance and defeat those obligations added under the modified contract. This rule does not burden limited judicial resources. When the promisee achieves self-help specific performance, the court is involved in the remedy at the stage when performance is satisfactorily completed. The court does not have to enforce and oversee the contract's performance. It simply refuses to enforce the modification.

Where the terms of the contract are uncertain, however, and the parties make a modification in the process of defining the performance due, the self-help remedy should continue to be unavailable, that is, the modification should be enforced. ${ }^{128}$ In such cases, it is likely that the parties had inconsistent expectations regarding performance, and the modification is an attempt to resolve the problem. A modification which resolves uncertain terms should be enforced. If the modification is not made in the process of resolving a valid disagreement, however, the promisee should have a right to receive self-help specific performance, even if the terms would have been uncertain for the purposes of awarding specific performance.

It is obviously more difficult to justify the self-help remedy in these

behind the cost-of-completion remedy that is decreed in many suits involving the defective performance of such contracts. The cost of completion measures damages by the amount needed to complete the project according to the contract specifications, rather than by the reduction in market value of the property because of the defective performance. The cost of completion is, therefore, a specific performance remedy.

The cost-of-completion remedy is subject to strategic behavior on the part of the disappointed party where the cost to complete the project is disproportionately great compared to the loss in market value associated with the defective performance. In such cases, courts may award only the difference in market value. In the classic example, Jacobs \& Young Inc. v. Kent, 230 N.Y. 239, 129 N.E. 889 (1921), a contractor who had installed pipe of a brand different than that specified in the contract was not required to pay the cost of replacing all the pipe in a house. While this decision may be explained on efficiency grounds, it can also be interpreted as an attempt to deter opportunism. It seems likely that in many such cases of apparently de minimis inadequacy, the disappointed party is really attempting to reap a large award, while being relatively indifferent to the alleged inadequacy.

126. "Specific performance or an injunction will not be granted unless the terms of the contract are sufficiently certain to provide a basis for an appropriate order." RESTATEMrNr, supra note 5, $\S$ 362.

127. The courts' reluctance to award specific performance when the contract is not clearly defined is partly explained by the liberty rationale discussed in detail later in this paper. See infra notes 143-46 and accompanying text. When a court forces a promisor to perform duties not required by the original contract, the court infringes on a promisor's liberty to allocate his services.

128. For example, if a contract calls for construction of a "first class theatre" and the promisee wants marble stalls, while the promisor insists that such stalls are not part of a "first class theatre," and the modification requires the marble stalls at a higher price, the promisee should be required to perform the modification. This also could be justified as a modification supported by consideration. For a discussion of the opportunism problems associated with this solution, see supra note 60 . 
cases than in those where a promisee would have been entitled to specific performance. Here, the promisee can obtain more from the promisor through the self-help route than through a lawsuit. The promisee therefore has a greater incentive to act opportunistically. Nevertheless, the selfhelp specific performance remedy is justified, since these are the cases in which promisors have the greatest opportunity for strategic behavior.

To demonstrate, assume that $B$ can show that the contract parts are unique, but also assume that the supply contract is to run for several years and the quality of the parts is critical and difficult to police. The difficulty of monitoring performance and the likelihood of future litigation will probably lead the court to deny specific performance. ${ }^{129}$

This time, $B$ and $S$ are aware that $B$ may not be able to obtain specific performance. The contract price would therefore not include the cost of the specific performance remedy. But $S$ must also know that the goods have limited substitutes: His monopolistic ability to exploit $B$ midstream is at a maximum. The potential for exploitation includes not only litigation costs, delay costs, and the disparity between compensable damages and actual losses, but also the costs imposed upon $B$ by the fact that the performance is very difficult to replace. ${ }^{130}$ Furthermore, unlike the usual case of non-compensable damages, $B$ will find it difficult to protect-herself in the initial contract. ${ }^{131}$

Gan $B$ exploit $S$ ? By modifying the contract, receiving performance and then refusing to honor the modification, $B$ receives specific performance. $B$ also avoids the significant losses that the damage remedy imposes, including delay problems.

In deciding whether to follow this route, $B$ does not have to consider $S$ 's costs of performing and whether these costs are balanced by the gains accruing to $B$. But this is the case where the gains to $B$ are most likely to exceed the costs to $S$ : Where $S$ 's performance is not replaceable, the gains to $B$ of $S$ 's performance are likely to exceed those in a contract for a fungible market performance.

129. See, e.g,, Yonan v. Oak Park Fed. Sav. \& Loan Ass'n, 27 Ill. App. 3d 967, 974, 326 N.E.2d 773,779 (1975) (specific performance denied for construction contract where further litigation likely).

130. Some of the factors which create the potential for opportunism here are present in all cases where damages are inadequate and have been used to support the theory that promisees are almost always driven to modify because of inadequate damage remedies. See supra note 79 and accompanying text.

The case where specific performance is denied for non-fungible goods is distinguishable, however, from the case where inadequate damages are awarded for fungible goods. The extortion potential is likely to be more extreme in the case of non-fungible goods. The promisee is unlikely to be able to avoid the consequences of the damage allocation (one reason why damages unforeseeable to the other party are noncompensable). Nor can the promisee protect herself in the initial contract (a clause providing for specific performance would obviously not be enforced). Thus, if the administrative system did not impose costs of its own, there would be little doubt that specific performance is theoretically preferable to the damage remedy. The fact that the contract would not include this cost, however, does allow promisee opportunism.

131. To the extent that it is realistic to do so, $B$ may be able to design her product to adapt to a range of tolerances. 
Thus, where damages are inadequate but specific performance is not available, $S$ may use the value of his irreplaceable performance to exploit $B{ }^{132} B$, for her part, can use modification to receive specific performance-more than her contractual due-without considering whether the cost of $S$ 's performance exceeds the benefits which accrue to $B$. In this situation, therefore, the legal rule cannot prevent exploitation. The only way to minimize exploitation-requiring specific performance-is impracticable under the judicial system. The legal system must select a second best solution. In this case, $S$ appears to have greater potential to exploit the contractual relationship than $B$. In addition, in this case the returns to $B$ from $S$ 's performance are greatest and most likely to be justified. For these reasons $B$ should have the option here of self-help specific performance.

An additional argument against giving $B$ the self-help right is that the remedy will reduce $S$ 's willingness to modify and thus increase $S$ 's incentives to breach. ${ }^{133}$ Thus this rule, intended to shield $B$ from opportunism, might actually deny $B$ the opportunity to receive the performance she needs.

But consider $S$ 's incentives when $B$ may modify and contest, but specific performance is unavailable. If $S$ modifies and performs, he might not receive the modified price. If $S$ breaches, he will not have to perform and will only pay damages. Where $S$ prefers breach and payment of damages to performance at the contract price, he will be reluctant, under a rule allowing $B$ to modify and renege after performance, to modify. $B$ 's ability to induce $S$ to perform is reduced in instances where the performance is most necessary to $B$. Note, though, that this will occur only in a limited number of cases. Where $S$ can justify the modification under current law, $B$ is liable for the modified price. Moreover, where $S$ 's actions are a purely opportunistic attempt to extract a higher price, he has no reason to prefer breach. $S$ will only prefer breach if the cost of performance, including the opportunity cost, exceeds the damage award he would be required to pay.

\section{b. Specific Performance Unavailable Because of Concerns of Fairness or Public Policy}

Sometimes a court will refuse specific performance if it finds the underlying contract unfair. ${ }^{\text {134 }}$ Unfairness may consist simply of a "grossly inad-

132. Sources of exploitation include litigation costs, time pressures and the inadequacy of the damage remedy in addition to all the usual sources of exploitive potential.

133. $A \mathrm{n}$ increased incentive to breach occurs only where the modification would not be enforced. Thus, if $S$ can demonstrate that the modification is justified, see supra notes 65-69 and accompanying text, the modification is enforceable. This rule only operates when the promisee agrees to an otherwise unjustified modification, in order to receive the performance to which she would not have been entitled under the law of remedies.

134. See Restritrment, supra note $5, \S 364$. While damages are theoretically available, specific 
equate"185 exchange, or bargaining irregularities such as mistake or duress. ${ }^{136}$ As an equitable, and hence discretionary, remedy, specific performance may not be granted even where these difficulties would not constitute a defense in an action for damages. Specific performance may also be refused for reasons of public policy, for example when it would result in a preference over the assets of an insolvent party. The burden on the judicial administration system is another such public policy rationale, as is the refusal to grant specific performance of personal service contracts. ${ }^{137}$

Modifications should be enforced where specific performance would have been refused for reasons either of public policy ${ }^{138}$ or unfairness. While there are convincing reasons to make the rules governing enforcement by specific performance identical to those governing damages, ${ }^{139}$ this goal should not be achieved by expanding the self-help modification remedy.

If a contract is so unfair that the court will not require specific performance, it is hard to see how allowing the promisee to achieve specific performance by self-help modification can do more than exacerbate the perceived unfairness. If the rationale for refusing specific performance is that the initial price was unfair, there is no justifiable reason for refusing to enforce a modified-and more fair-price after the promisee has tricked the promisor into rendering the promised performance. ${ }^{140}$ If the unfairness consisted of procedural irregularities, it is ludicrous to allow a

performance is often sought because damages are not readily provable. In these cases, the denial of specific performance is tantamount to a denial of all remedies. See Frank \& Endicolt, Defenses in Equity and "Legal Rights," 14 LA. L. Rrv. 380, 381 (1954). In such cases, permitting a promisee to modify, receive performance and then contest, thereby placing the burden on the promisor to justify the modification, creates an all-or-nothing game, as the promisee would have received nothing in a suit to enforce the original contract. The situation is exacerbated by the difference in perspective of the decision makers: In a suit for specific performance the person seeking the performance is suspect. In a suit to enforce a modification, the person seeking to enforce the modification is suspect.

135. REsi'ATEMENI, supra note $5, \S 364(1)$ (c).

136. Some of the unfairness concerns are designed to ensure that the party required to perform receives his rights under the contract. See, e.g., id. \$363.

137. Id. \$367 comment a.

138. This generalization does not cover contracts which place a burden on the judicial system, which have been dealt with, supra notes 125-29 and accompanying text, and contracts for personal services, discussed infra notes 142-46 and accompanying text.

139. See, e.g., Schwartz, supra note 87, at 298-303. While the defenses to an action for damages and an action for specific performance should be identical, I am not convinced that the defense of too low a price should be abolished. I suspect that the courts' refusal to award specific performance in these cases is based on a recognition that money damages undercompensate and a desire, in some cases, to confine promisees to undercompensatory remedies. This approach may be justified in some cases. Further discussion of these issues is, however, outside the scope of this Article.

140. See, e.g., Mckinnon v. Benedict, 38 Wis. 2d 607, 157 N.W.2d 665 (1968), where the court refused specific performance of the promisor's covenant to refrain from developing his land in a particular way, in part on the ground that the price was unfair. If instead of suing for specific performance, the promisee had agreed to give the promisor an additional sum to forego the business opportunity, and, once the opportunity was withdrawn, contests the modification, should the promisee win? As the law stands, the court would probably try to find the opportunity represented in an unforeseen circumstance. Contracts, however, are supposed to allocate opportunity costs. 
promisee to achieve greater remedies by misleading the promisor into believing that the initial problems have been corrected by modification. ${ }^{141}$ Moreover, refusing to enforce modifications here will increase a promisee's incentive to act opportunistically.

Of course, a rule that denies the promisee the self-help remedy increases the promisor's incentive to ask for a modification or threaten breach. Where the damage remedy is a more costly alternative than agreeing to the modified price, the promisee will be coerced into consent. But this coercion arises because of the inadequacy of the damage remedy. Such problems should be addressed through reforms in the system of contractual remedies, not through the modification process. The promisee is not obtaining more than she could through the contract remedy system.

\section{Specific Performance Unavailable Because of the Liberty Interest: Personal Service Contracts}

Usually, contracts for personal services will not be specifically enforced, although in some instances the person may be enjoined from rendering her services elsewhere. ${ }^{142}$ Several factors explain the courts' reluctance. First, it is difficult to determine whether personal service contracts have been adequately performed. Second, where the services require cooperation between the parties, it is undesirable and unrealistic to compel continued association after the contractual relationship has been disrupted. Third, promisors have a liberty interest in not being compelled to provide personal services. ${ }^{143}$ The first two reasons-fundamentally problems of judicial administration-do not justify depriving a promisee of the ability to modify and contest where specific performance would otherwise be appropriate. $^{144}$ The service will be rendered before the modification is contested; the court is no longer required to evaluate the quality of the performance. Nor is there a need to compel further cooperation between the parties.

Finally, I conclude that the liberty interest ${ }^{145}$ should not defeat the

141. See Perlmutter v. Bacas, 219 Md. 406, 149 ^.2d 23 (1959). The court refused specific performance of a land sale contract in which the buyer had made a mistake as to the acreage of the sale property. The result should not depend upon whether the seller sues for specific performance, or agrees to a lower price and then waits until the contract is consummated before suing for the difference.

142. RFsrarrmeNr, supra note $5, \S 367$. The factors involved in determining if a contract may be enforced by an injunction are complex. An injunction may be granted only if damages are inadequate, such as if the services contracted for are unique. Nevertheless, an injunction will not be used to force a person to perform. Nor will an injunction be granted if performance is the probable result, but personal factors make continued association between the promisor and promisee unpleasant. Id. comment $c$.

143. Id. comment a.

144. See supra notes $125-27$ and accompanying text.

145. Professor Schwartz suggests that liberty interest objections cannot be fully evaluated without considering: (1) the right to contract on one's own terms, including implied terms of specific performance; (2) the right to be free from undue compulsion to perform contracts; (3) the goal of minimizing the costs of undercompensation; and (4) the objective of giving the promisee the performance she bargained for. Schwartz, supra note 87, at 297. 
promisee. A large element of the liberty interest-not being compelled to associate with others (or forced to remain in an unpleasant environment)-will be absent by the time of judicial enforcement. The promisor's performance was willingly given, even if he mistakenly believed that the contract had been modified. The promisor will be compelled to accept a lower price than he was willing to accept at the time of performance, although he did consent to this price when the contract was created. ${ }^{148}$ Moreover, while the self-help remedy may impinge somewhat on the promisor's liberty interest, the promisee should have an equivalent liberty right that protects her from being subject to a promisor's opportunistic attempts to extract more for the promised performance.

Whether promisees should be allowed to modify and contest personal service contracts depends on the relative weights given to the promisor's right to choose between damages and performance in a personal service contract, and the promisee's right to be free from opportunism. Professor Kronman has noted that the objection to forcing performance of personal service contracts has been overdrawn. ${ }^{147}$ While even voluntary servitude can be objectionable, it does not follow that any compulsion of services is objectionable. The appropriateness of compelling performance will turn on the extent to which the contractual relationship infringes upon personal liberty and the manner of the infringement. ${ }^{148}$ If a grant of specific performance does not seriously infringe upon liberty, and the problems of compelling unwilling association are absent, the fact that the contract is for personal services should not allow the promisor greater scope to extract a higher price midstream than in any other type of contract. The court must not, however, allow promisees the opportunity to expand their rights beyond those given in the contract.

The self-help remedy should certainly be available where the promisee

146. In fact, the promisor is being required to perform at a somewhat lower price than that set in the initial contract. Under the initial contract the promisee did not have a right to specific performance; the promisor would have settled his contractual obligations through payment of admittedly undercompensatory money damages. Even though these are cases where the promisee is most likely to want specific performance, the judicial system prohibits her from obtaining this remedy. It is also unlikely that the promisor will agree to an irrevocable commitment to perform; but if he does, he will at least charge the highest price for this privilege.

This section is particularly concerned with modifications that represent an opportunistic attempt by an irreplaceable employee to exploit her relationship. See Schwartzreich v. Bauman-Basch, Inc., 231 N.Y. 196, 131 N.E. 887 (1921). In Schwartzreich, the services offered by the employee were unique. As soon as the employee found a higher paying offer, he asked for a raise. Enforcement of this type of modification has been justified on the grounds that alternative offers reflect a real opportunity cost and should justify modifications. See Posner, Gratuitous Promises in Economics and Law, $6 \mathrm{~J}$. LEGAL STud. 411, 424 (1977). But opportunity costs are always present and are supposed to be part of the risk allocated by the contract. Cf. Muris, supra note 1, at 536-37 (discussing Schwartzreich and modification doctrine).

147. Kronman, Specific Performance, 45 U. CHI. L. Rev. 351, 372-73 (1978).

148. Thus, a lifetime contract to render services is objectionable, while a contract for a much more limited period is not. Similarly, a contract giving an employer the right to send employees into a coal mine without protection is unacceptable. But these contracts should not be enforceable at all, whether by damages or by specific performance. 
could have obtained an injunction against the promisor preventing him from performing for someone else at a higher price. In these cases, the judicial system is willing to interfere with the promisor's freedom. ${ }^{149}$ The contract price incorporates at least part of the added price the promisor would have received for granting the promisee a contractual right to specific performance: While the right to an injunction might not increase the promisee's benefits, it is costly to the promisor: Moreover, the availability of an injunction will place increased pressure on the promisor to render the promised performance. ${ }^{130}$ To this extent, the case is equivalent to one in which specific performance is available. Where injunctive relief would not result in performance, the promisee can expand her rights through modification. But, given the potential for strategic behavior by the promisor, the minimal interference with the promisor's liberty, and the minimal potential for promisee opportunism, the self-help specific performance remedy should be available to the promisee.

A rule allowing the promisee to modify is justified even if an injunction would be denied because its "probable result . . . will be to leave the employee without other reasonable means of making a living."161 In this situation the promisor is well situated to extract a better deal midstream. On the other hand, however, the contract most clearly does not include any specific performance right for the promisee. The legal system must choose between two evils. This analysis concludes that the potential for exploitation inherent in a threat to withdraw an irreplaceable service in midstream is usually much greater than that reflected in the differing valuations of the two remedies that would have affected the original contract price. $^{132}$ Thus, a rule allowing promisees to modify in order to receive the service is in order.

A rule allowing promisees to modify and contest will eventually result

149. The difficult case is one in which the promisor could have worked at a different skill for a higher price. Then the promisor might have elected to take the alternate, higher paying employment. The availability of this option would reduce both the coerciveness and cost of the injunction to the promisor.

150. While injunctions will be refused if they force an employee's performance (i.e., if the person has no other means of earning a living), it is also understood that performance will be the probable result of an injunction. Hence the Restatement suggests that injunctions should not be granted where performance is the probable result unless "the employer is prepared to continue the employment in good faith. . . RESTATEMENT, supra note $5, \S 367$ comment c.

151. Id. \& $367(2)$.

152. This reasoning provides the best rationalization for the rule in Schwartzreich v. BaumanBasch, Inc., 231 N.Y. 196, 131 N.E. 887 (1921). In this case, a threat to withdraw a non-fungible service was used to extract a contractual modification. The employer would almost certainly not have obtained an injunction. (There was no indication that the promisee was affected by the identity of the alternative employer, so the injunction would have applied to any potential employer. Hence, the availability of injunctive relief would have interfered with the promisor's ability to earn a living.)

If our fear of the promisee's ability to take advantage of opportunistic potential, especially in an area traditionally viewed as particularly sensitive, is given greater weight than the fear of the promisor's opportunistic potential, a rule should be established that would deter promisec opportunism. Then, as in Schwartzreich, modifications that are contested after performance is given would be enforced. 
in the decreased willingness of promisors to modify rather than breach. This effect will not be as great in cases where injunctions are available because the cost of breach to promisors is greater. ${ }^{153}$ Where only damages are available though, breach might be significantly less costly. The only way to resolve this problem is to alter the law of damages so that promisors do not face a significant disparity between the cost of performance and the cost of breach.

\section{CONCLUSION}

There is little justification for treating self-help measures as a special category of remedy. Self-help measures must be integrated within the overall framework of contract remedies. Modification doctrine creates a self-help route to specific performance and, thus, must be integrated within the system of legal remedies for breach of contract.

Self-help specific performance is justified in two circumstances. First, a promisee should be entitled to the self-help remedy where specific performance would have been decreed in a suit to enforce the contract. The standard legal remedy of specific performance is often empty because of the delays attendant upon the litigation process, or because the success of the performance depends upon the good-faith efforts of the contracting parties. In such cases, a promisee's right to self-help reduces incentives for promisor opportunism, reduces administrative costs, and converts a legal right to specific performance into a realistic remedy.

Second, the self-help remedy should be available in cases where specific performance is appropriate to further the goals of contract, but is not available because of the problems inherent in administering such a remedy. Allowing the self-help remedy here would increase the incentives for promisee opportunism, but this is more than offset by the fact that in these cases the incentives for promisor opportunism are far greater. ${ }^{164}$

These suggestions may easily be integrated within the current trend toward reformulating modification doctrine to reflect the concerns of duress. Commentators on modification have tended to retain the perspective of traditional modification doctrine-that it is only the party seeking the change who acts opportunistically - while suggesting that modification reflects the concerns of duress. Hence these scholars interpret "duress" standards from the perspective that only the party seeking the modification

153. When injunctions are available, costs to the promisors are higher for the same reasons that they are higher in cases in which specific performance would be granted. See supra notes 118-19 and accompanying text.

If parties really do see a liberty interest in either not performing at a given price or in not being tricked into performance, promisors will be equally reluctant to modify all personal service contracts. I believe, however, that these same liberty interests exist in all services, whether they are personal or involve the delivery of goods.

154. See supra notes $125-33$ and accompanying text. 
need justify her actions. ${ }^{165}$ But traditional duress does not have this onesided focus. Classical duress doctrine recognizes that while the promisor might have "forced" the promisee to consent, by consenting the promisee may also have received something of value from the promisor. Classical duress therefore requires that, in order for the contract to be unenforceable, the promisee must demonstrate that she had "no reasonable alternative" but to agree to the promisor's suggestion: In applying this requirement in the context of modification, commentators and courts have accepted the argument that the inadequacy of the alternative of seeking damages for breach justifies allowing the promisee to employ the self-help remedy. This Article suggests that the damage remedy must be considered a "reasonable alternative." In general, the promisee may justify her selfhelp remedy by showing either that she would have been entitled to specific performance or that specific performance, while theoretically preferable, would be unavailable for reasons of administrative limitation. This would provide an easily applied, bright-line rule to control promisee opportunism in modification.

A right to modify and contest cannot be justified where the preferred legal remedy for breach is payment of damages. In such cases, the right to modify, receive the promised performance, and then renege upon the modification creates incentives for promisee opportunism with no gains for the goals of contract enforcement.

155. See supra notes 78-79 and accompanying text. 